\title{
Pengaruh Penggunaan Lembar Kerja Peserta Didik (LKPD) Berbasis ExCluSiVE pada Pembelajaran Alat Optik terhadap Kemampuan Berpikir Kreatif
}

\author{
Siti Nurmahudina ${ }^{1}$, I Wayan Distrik ${ }^{2}$, dan Ismu Wahyudi ${ }^{3}$ \\ 1,2,3 Universitas Lampung \\ e-mail: siti.nurmahudina@gmail.com
}

\begin{abstract}
The use of today's learning media is crucial in enhancing the creative thinking skills of learners. The aim oh this research is to know the effect of using exclusive LKPD based on optical tool learning to creative thinking skills. The population in this research is XI class students in SMA Negeri 1 Sumberejo, and the research samples are XI IPA 1 and XI IPA Class 2 even semester 2018/2019 school year. The design of this research uses nonequivalent control group design. The $N$-gain value of the research results will be tested using the Independent Sample T-Test. The Independent Sample T-Test test results gained a significant $N$-gain difference with the significance rate of $<0.05$, meaning there is a significant influence on the use of LKPD ExCluSiVE based on optical tool learning to the students ' creative thinking skills.
\end{abstract}

Keywords: optical tools, ExCluSiVE, creative thinking ability

\begin{abstract}
Abstrak. Penggunaan media pembelajaran saat ini sangat penting dalam meningkatkan kemampuan berpikir kreatif peserta didik. Penelitian ini dilakukan dengan tujuan untuk mengetahui pengaruh penggunaan LKPD berbasis ExCluSiVE pada pembelajaran alat optik terhadap kemampuan berpikir kreatif. Populasi pada penelitian ini adalah peserta didik kelas XI di SMA Negeri 1 Sumberejo, dan sampel penelitiannya adalah kelas XI IPA 1 dan XI IPA 2 semester genap tahun ajaran 2018/2019. Desain penelitian ini menggunakan non-equivalent control grup design. nilai N-gain yang diperolah dari hasil penelitian akan diuji menggunakan uji Independent Sample TTest. Hasil uji Independent Sample T-Test diperoleh perbedaan N-gain yang signifikan dengan tingkat signifikansi $<0,05$, berarti terdapat pengaruh yang signifikan penggunaaan LKPD berbasis ExCluSiVE pada pembelajaran alat optik terhadap kemampuan berpikir kreatif peserta didik.
\end{abstract}

Kata kunci: alat optik, ExCluSiVE, kemampuan berpikir kreatif

\section{PENDAHULUAN}

Proses pembelajaran merupakan pokok dari keseluruhan proses pendidikan di sekolah. Berhasil atau gagalnya ketercapain tujuan pembelajaran secara langsung dipengaruhi oleh proses pembelajaran yang dialami oleh peserta didik. Guru dituntut untuk menguasai berbagai strategi ataupun model pembelajaran, agar guru mampu mengatasi kejenuhan yang dialami peserta didik 
selama proses pembelajaran. Kreativitas yang dimiliki oleh peserta didik berhubungan dengan kemampuan berpikir tingkat tinggi yang dimilikinya. Kemampuan berpikir tingkat tinggi mengharuskan individu dan masyarakat memiliki kemampuan untuk senantiasa belajar, bernalar, berpikir kreatif, membuat keputusan dan memecahkan masalah (Pusfarini dkk., 2016). Berpikir tingkat tinggi mencakup dari kemampuan berpikir kreatif. Berpikir kreatif menurut Saefudin (2012) secara khusus dapat dikatakan berpikir kreatif sebagai satu kesatuan atau kombinasi dari berpikir logis dan berpikir divergen guna menghaisilkan sesuatu yang baru, baik dalam profesi pendidikan maupun profesi lainnya yang menuntut sumber daya manusia pola pikirnya dapat berkembang.

Berdasarkan informasi yang diperoleh di SMA Negeri 1 Sumberejo bahwa minimnya proses pembelajaran dengan melakukan praktikum atau percobaan secara langsung. Hasil wawancara dari beberapa peserta didik di SMA Negeri 1 Sumberejo, mereka menyatakan bahwa pembelajaran fisika akan lebih menarik apabila terlibat dengan pengalaman dan lingkungan secara langsung. Peserta didik juga mengatakan bahwa pembelajaran akan lebih menarik apabila dilengkapi dengan media pembelajaran yang memadai, dan akan membuat mereka lebih mudah memahami teori yang disampaikan oleh guru. Berdasarkan kenyataan di lapangan peserta didik masih kurang dalam hal kemampuan berpikir kreatif, hal tersebut terjadi karena peserta didik tidak diberikan kesempatan untuk mengeksplor pengetahuannya dengan melakukan kegiatan pembelajaran secara langsung atau praktikum. Faktor penyebabnya adalah keterbatasan peralatan yang di laboratorium sekolah. Faktor lain diantaranya yaitu media yang belum memadai.

Ada beberapa hal yang mendukung pembelajaran untuk meningkatkan kemampuan berpikir kreatif, salah satunya media pembelajaran berupa Lembar Kerja Peserta Didik (LKPD). LKPD didesain sesuai dengan tujuan dan karakteristik materi. LKPD yang dirancang untuk mencapai kemampuan berpikir kreatif peserta didik slah satunya adalah LKPD berbasis exclusive.

Salah satu model pembelajaran yang memfokuskan pada kemampuan berpikir dan mengidentifikasi permasalahan yaitu model pembelajaran ExCluSiVE. Model pembelajaran ExCluSiVE merupakan akronim dari exploring, clustering, simulating, valuing, and evaluating. Menurut Abdurrahman, dkk. (2012) model pembelajaran ExCluSiVE menuntut peserta didik untuk saling bertukar pikiran, berkolaborasi, berkomunikasi, serta bersimulasi di depan kelas untuk mencapai tujuan pembelajaran yang diinginkan. Peserta didik diharapkan mampu mengembangkan kemampuannya, terutama kemampuan berpikir kreatif pada indikator kemampuan berfikir elaborasi dan evaluatif. Pengggunaan model pembelajaran mampu memberikan solusi terbaik bagi guru merencanakan pembelajaran, karena model pembelajaran memiliki langkah-langkah yang sistematis untuk mencapai tujuan dari pembelajaran. Pendapat tersebut didukung oleh Sagala 
(2005) yang mengemukakan bahwa model pembelajaran adalah kerangka konseptual yang melukiskan prosedur sistematis pengalaman belajar peserta didik untuk mencapai tujuan tertentu, berfungsi sebagai pedoman dalam perancang pembelajaran dan guru dalam merencanakan dan melaksanakan kegiatan belajar mengajar. Saat ini sudah banyak yang mengembangkan berbagai bentuk model pembelajaran, salah satunya model pembelajaran ExCluSiVE (Exploring, Clustering, Simulating, Valuing, and Evaluating).

Model ini dikembangkan berdasarkan teori konstruktivisme, yaitu salah satu filsafat pengetahuan yang menekankan pengetahuan kita adalah bentukan (konstruksi) kita sendiri. Model pembelajaran ExCluSiVE juga dikembangkan berdasarkan teori metakognisi yang menitik beratkan pada pengetahuan kesadaran dan proses atau kendali. Menurut Wiliyanti, dkk (2014) Dampak yang diperoleh peserta didik setelah diterapkan pembelajaran Exclusive di kelas tidak hanya dapat merubah dan meningkatkan kemampuan peserta didik dari ranah kognitif, afektif, dan psikomotor saja, namun juga perubahan lainnya berupa bertambahnya nilai-nilai positif peserta didik dan sikap kritis dalam belajar, hal ini tentu merupakan tujuan dari belajar yang diharapkan baik peserta didik maupun guru. Aburrahman dkk., (2012) memaparkan bahwa model pembelajaran ExCluSiVE berguna dalam mengkaji fakta atau fenomena yang ada di lingkungan sekitar dan terkait dengan pengalaman nyata peserta didik sehari-hari. Model ini sesuai dengan teori konstruktivisme, yaitu salah satu filsafat pengetahuan yang menekankan bahwa pengetahuan kita adalah bentukan (konstruksi) kita sendiri. Model pembelajaran ExCluSiVE juga sesuai dengan teori metakognisi yang menitik beratkan pada pada pengetahuan kesadaran dan proses atau kendali.

Langkah-langkah pada sintaks pembelajaran ExCluSiVE menurut Pahini, dkk (2014) yaitu diawali dengan exploring untuk mencari informasi sebanyak-banyaknya tentang materi yang akan dibahas, clustering untuk spesifikasi pada pembahasan materi, simulating untuk melakukan simulasi berdasarkan pembahasan materi pada kelompok cluster, valuing untuk me-nyampaikan dan menyimpulkan apa saja yang telah diperolehnya atau dipahami peserta didik, dan diakhiri dengan evaluating untuk mengeveluasi jalan-nya keseluruhaan proses pembelajaran sehigga memperoleh sejumlah rumusan rekomendasi perbaikan pada kegiatan pembelajaran berikutnya.

Berpikir kreatif adalah penggunaan dasar konsep berpikir untuk mengembangkan ataupun menemukan ide dan informasi yang berhubungan dengan konsep, dan pandangan yang penekannya ada pada aspek berpikir untuk menjelaskan gagasan dengan perspektif asli pemikir. Menurut Amer (2005) berpikir kreatif merupakan suatu proses menciptakan suatu hal ataupun ide-ide yang sebelumnya tidak saling berhubungan.Berdasarkan pemaparan yang dikemukakan Amer, dapat disimpulkan bahwa manusia yang berpikir kreatif tergolong cerdas dan berbakat 
khusus karena mampu mengemukakan hal-hal baru. Proses berpikir kreatif membutuhkan imajinasi untuk menemukan atau menciptakan ide-ide yang tidak saling berhubungan menjadi kesatuan yang baru.

Baer (2014) mengemukakan bahwa berpikir kreatif adalah sinonim dari berpikir divergen. Terdapat 4 indikator berpikir divergen yaitu, (1) fluence, adalah kemampuan menghasilkan banyak ide, (2) flexibility, adalah kemampuan menghasilkan ide-ide yang bervariasi, (3) originality, adalah kemampuan menghasilkan ide baru atau ide yang sebelumnya tidak ada, dan (4) elaboration, adalah kemampuan mengembangkan atau menambahkan ideide sehingga dihasilkan ide yang rinci atau detail. Lebih lanjut Baer (1993) mengemukakan kreativitas seseorang ditunjukkan dalam berbagai hal, seperti kebiasaan berpikir, sikap, pembawaan atau kepribadian, atau kecakapan dalam memecahkan masalah.

Kemampuan berpikir kreatif peserta didik dalam menyelesaikan persoalan dapat dinilai dengan beberapa kriteria. Indikator berpikir kreatif peserta didik menggunakan acuan yang dibuat Munandar (2004) yang meliputi kefasihan, fleksibilitas dan kebaruan. Indikator berpikir kreatif dalam memecahkan masalah diantaranya: 1) kemampuan berfikir lancar/kefasihan (memberikan banya- $k$ kemungkinan jawaban atau gagasan atas pertanyaan yang diajukan); 2)puan berfikir luwes/ fleksibelitas (menghasilkan jawaban yang bervariasi dengan sudut pandang yang berbeda); 3) kemampuan berpikir orisinil (Dapat memberikan jawaban atau pertanyaan yang diberikan menurut pemikiran- nya sendiri); 4) kemampuan memperinci/mengelaborasi (dapat memperinci suatu gagasan atau jawaban sehingga lebih jelas); 5) Kemampuan menilai/mengevaluasi (mampu menyimpulkan mengenai masalah yang dipecahkan).

Menurut Damayanti, dkk. (2017) LKPD berbasis ExCluSiVE ini dapat digunakan secara mandiri, di dalamnya berisis percobaan yang berkenaan dengan alat-alat Alat optik yang disusun berdasarkan sintak model pembelajaran ExCluSiVE yaitu: exploring, clustering, simulating,valuing, dan evaluating. Ketersediaan LKPD ini dapat membantu peserta didik lebih mudah memahami materi Alat optik melalui percobaan yang dilakukan, sehingga penelitan ini bertujuan untuk mengetahui pengaruh penggunaan LKPD berbasis ExCluSiVE pada pembelajaran alat optik terhadap kemampuan berpikir kreatif. Sebagai salah satu upaya untuk meningkan kemampuan berpikir kreatif, penulis perlu mengetahui seberapa besar pengaruh penggunaan LKPD berbasis model pembelajaran ExCluSiVE terhadap kemampuan berpikir kreatif peserta didik, karena itu penulis melakukan penelitian yang berjudul "Pengaruh Penggunaan LKPD Berbasis ExCluSiVE pada Pembelajaran Alat optik terhadap Kemampuan Berpikir Kreatif” 


\section{METODE}

Penelitian ini adalah penelitian eksperimen dengan Populasi penelitian yaitu seluruh peserta didik kelas XI IPA di SMA Negeri 1 Sumberejo, semester genap tahun ajaran 2018/2019. Sampel penelitian ditentukan dengan menggunakan teknik pengambilan sampel secara purposive sampling yaitu pemilihan kelas sebagai sampel dengan karakteristik yang relatif homogen. Kelas eksperimen dengan menggunakan treatment LKPD berbasis model pembelajaran ExCluSiVE, sedangkan pada kelas kontrol dengan menggunakan LKPD konvensional di sekolah. Hasil pembelajaran yang diukur yaitu kemampuan berpikir kreatif peserta didik pada saat pembelajaran, hasil dari kemampuan berpikir kreatif pada kelas eksperimen dibandingkan dengan kemampuan berpikir kreatif pada kelas kontrol. Sehingga dapat diketahui adanya perbedaan kemampuan berpikir kreatif antara kelas eksperimen dan kelas kontrol.

Metode penelitian yang digunakan adalah quasi experimental, dengan menggunakan desain non-equivalent control grup design. Pada desain ini terdapat pretest sebelum diberi perlakuan dan posttes setelah diberi perlakuan. Kelas eksperimen diberi perlakuan menggunakan LKPD berbasis ExCluSiVE, sedangkan kelas kontrol menggunakan LKPD yang biasa digunakan di sekolah. Hasil pretest dan posttes pada kedua kelas subyek dibandingkan. Desain Eksperimen Non-Equivalent Control Grup Design dapat dilihat pada Gambar 1.

\begin{tabular}{|ccc|}
\hline $\mathrm{O}_{1}$ & $\mathrm{X}$ & $\mathrm{O}_{2}$ \\
$\mathrm{O}_{3}$ & - & $\mathrm{O}_{4}$ \\
\hline
\end{tabular}

Gambar 1. Desain Penelitian

Adanya pretest sebelum perlakuan, baik untuk kelas eksperimen maupun kelas kontrol (O1, O3), dapat digunakan sebagai dasar dalam menentukan perubahan. Menurut pendapat Emzir (2012: 105) pemberian posttest (O2, O4) pada akhir kegiatan akan dapat menunjukkan seberapa jauh perbedaan akibat perlakuan $(\mathrm{X})$.

Data hasil penelitian ini berupa data kuantitatif yang didapatkan dari hasil pretest dan posttest. Instrumen tes yang digunakan untuk mengetahui data kuantitatif berpikir kreatif peserta didik. Uji validitas dan reliabilitas dilakukan untuk menganalisis instrumen yang digunakan dalam penelitian. Pengujian validitas instrumen pada penelitian ini dengan korelasi product moment dengan menggunakan aplikasi SPSS 22.0. Kriteria pengujian jika korelasi antar butir dengan skor total lebih dari 0,3 maka instrumen tersebut dinyatakan valid, atau sebaliknya jika korelasi antar butir dengan skor total kurang dari 0,3 maka instrumen tersebut dinyatakan tidak valid. Uji reliabilitas 
merupakan indeks yang menunjukan sejauh mana alat pengukuran dapat dipercaya untuk penelitian. Tolak ukur untuk menginterpretasikan derajat reliabilitas dapat dilihat pada Tabel 1.

Tabel 1. Kriteria indeks Reliabilitas

\begin{tabular}{rc}
\hline Koefisien Korelasi & Kriteria Reliabilitas \\
\hline $0,800-1,000$ & Sangat Tinggi \\
$0,600-0,800$ & Tinggi \\
$0,400-0,600$ & Cukup \\
$0,200-0,400$ & Rendah \\
$0,000-0,200$ & Sangat Rendah \\
\hline
\end{tabular}

Uji validitas dan reliabilitas yang telah dilakukan didapatkan bahwa 6 butir soal memiliki Pearson correlation $>0,3610$ sehingga 6 butir soal tersebut valid dan 4 butir soal yang lainnya tidak valid, karena memiliki Pearson Correlation < 0,361. Hasil uji reliabilitas instrumen pada soal yang valid didapatkan yaitu nilai Cronbach's Alpha sebesar 0,920 pada 6 soal valid, maka hasil uji tersebut dikatakan bersifat reliabel dan tergolong sangat tinggi karena berada pada rentang $0,80<\mathrm{r}<1,00$.

Analisis tes kemampuan berpikir kreatif yang menggunakan nilai pretest dan posttest, maka digunakan analisis $\mathrm{N}$-gain sebagai berikut:

$\mathrm{N}$-gain $=\frac{\text { skor posttest }- \text { skor pretest }}{\text { skor maksimum-skor pretest }}$

Kriteria interpretasi N-gain dapat dilihat pada Tabel 2.

Tabel 2. Kriteria Interpretasi $\mathbf{N}$-gain

\begin{tabular}{cc}
\hline $\mathbf{N}$-gain & Kriteria Interpretasi \\
\hline$g>0,7$ & Tinggi \\
$0,3 \leq g \leq 0,7$ & Sedang \\
$g<0,3$ & Rendah \\
\hline
\end{tabular}

Analisis data pada penelitain dilakukan dengan uji normalitas, uji homogenitas dan uji hipotesis. Uji normalitas pada penelitian menggunkan uji Kolmogorof-Smimov menggunakan bantuan program SPSS 22.0. kemudian uji homogenitas dilakukan untuk mengetahui data sampel yang digunakan mempunyai varians yang homogen atau tidak.

Pengujian hipotesis pada penelitian ini menggunakan uji statistik yaitu uji Independent Sample $T$ Test Uji ini dilakukan untuk membandingkan dua sampel yang berbeda (bebas). Independent Sample T-Test digunakan untuk mengetahui ada atau tidaknya perbedaan rata-rata antara dua kelompok sampel yang tidak berhubungan. Penelitian ini menguji Independent Sample TTest dengan menggunakan bantuan program SPSS 22.0. Berpedoman berdasarkan nilai signifikasi atau nilai probabilitas sebagai berikut : (1) Jika nilai signifikasi atau nilai probabilitasnya $<0,05$ maka H0 ditolak (2) Jika nilai signifikasi atau nilai probabilitasnya $\geq 0,05$ maka H0 diterima. 


\section{HASIL PENELITIAN}

Kegiatan pembelajaran penelitian berlangsung selama $3 \times 2 \times 45$ menit baik pada kelas eksperimen maupun pada kelas kontrol. Kelas XI IPA 2 sebagai kelas eksperimen yang mengimplementasikan LKPD berbasis ExCluSiVE, sedangkan kelas XI IPA 1 sebagai kelas kontrol yang menggunakan LKPD konvensional. Data kuantitatif hasil pretest berpikir kreatif dilakuakan pada awal, sedangkan hasil posttest berpikir kreatif dilakukan pada akhir pembelajaran peserta didik. Rerata hasil pretest berpikir kreatif peserta didik dapat dilihat pada Tabel 3. Sedangkan rerata hasil posttest berpikir kreatif peserta didik dapat dilihat pada Tabel 4.

Tabel 3. Data Rerata Hasil Pretest Berpikir kreatif Peserta Didik

\begin{tabular}{ccccc}
\hline \multirow{2}{*}{ No } & \multirow{2}{*}{ Kelas } & \multicolumn{3}{c}{ Nilai Pretest } \\
\cline { 3 - 5 } & & Terendah & Tertinggi & Rerata \\
\hline 1. & Eksperimen & 40 & 57 & 47 \\
2. & Kontrol & 33 & 57 & 45 \\
\hline
\end{tabular}

Tabel 4. Data Rerata Hasil Posttest Berpikir Kreatif Peserta Didik

\begin{tabular}{ccccc}
\hline & & \multicolumn{3}{c}{ Nilai Posttest } \\
\cline { 3 - 5 } No & Kelas & Terendah & Tertinggi & Rerata \\
\hline 1. & Eksperimen & 70 & 90 & 81 \\
2. & Kontrol & 47 & 74 & 61 \\
\hline
\end{tabular}

Peningkatan kemampuan berpikir kreatif peserta didik dapat dilihat dari selisih antara hasil tes sebelum diberikan perlakuan dengan hasil tes setelah diberikan perlakuan. Data kemampuan berpikir kreatif peserta didik dapat dilihat pada Tabel 5.

\section{Tabel 5. Hasil N-Gain Kemampuan Berpikir Kreatif}

\begin{tabular}{ccc}
\hline Kelas & Rerata N-gain & Kategori \\
\hline Eksperimen & 0,65 & Sedang \\
Kontrol & 0,28 & Rendah \\
\hline
\end{tabular}

Berdasarkan Tabel 5 dapat diketahui bahwa rerata peningkatan kemampuan berpikir kreatif peserta didik kelas eksperimen lebih tinggi dari rerata peningkatan kemampuan berpikir kreatif peserta didik kelas kontrol. Kategori dari rerata hasil $N$-gain menunjelaskan bahwa kelas ekperimen lebih tinggi yaitu kategori sedang, sedangkan kelas kontrol kategori rendah.

Uji normalitas dilakukan menggunakan progran SPSS 22.0 dengan metode KolmogrovSmirnov. Hasil uji normalitas N-gain kemampuan berpikir kreatif dapat dilihat pada Tabel 6. 
Tabel 6. Hasil Uji Normalitas

Berpikir Kreatif Kelas

Eksperimen

Kontrol
Kolmogrov-Smitnov

0,200

0,200

Data tersebut dikatakan normal karena memenuhi kriteria uji normalitas yaitu jika sig $>$ 0,05 maka data berdistribusi normal. Hasil ini merupakan salah satu syarat terpenuhinya untuk melakukan uji dua sampel bebas dengan menggunakan Independent Sample T-test. Setelah dilakukan uji normalitas, selanjutnya dilakukan uji homogenitas untuk mengetahui apakah varian data adalah sama atau tidak. Uji ini dilakukan dengan program SPSS 22. Variabel yang diuji homogenitasnya adalah $N$-gain rerata dari masing-masing kelas. Hasil uji homogenitas data hasil kemampuan berpikir kreatif peserta didik didapatkan bahwa nilai sig. 0,352, karena nilai signifikansi lebih dari 0,05, maka dapat disimpulkan bahwa kedua kelompok data mempunyai varian yang sama (homogen).

Langkah selanjutnya dilakukan pengujian dua sampel bebas menggunakan Independent Sample T-test untuk mengetahui ada tidaknya perbedaan hasil kemampuan berpikir kreatif peserta didik sebelum dan sesudah dilakukan pembelajaran pada masing-masing kelas (eksperimen dan kontrol). Adapun data yang diuji adalah perbedaan rerata $N$-gain dari masing-masing kelas eksperimen dan kontrol. Hasil yang didapatkan nilai Signifikasi sebesar 0,000 pada taraf kepercayaan 95\%, maka $\mathrm{H}_{0}$ ditolak. Tabel 8 membuktikan bahwa menurut uji Independent Sample T-test terdapat perbedaan hasil kemampuan berpikir kreatif peserta didik kelas eksperimen dan kelas kontrol secara signifikan. Maka dapat disimpulkan bahwa terdapat pengaruh penggunaan LKPD berbasis ExCluSiVE pada pembelajaran alat alat optik terhadap kemampuan berpikir kreatif peserta didik.

\section{PEMBAHASAN}

Perbedaan nilai rerata hasil belajar peserta didik pada kemampuan berpikir kreatif kelas eksperimen dan kelas kontrol dapat dilihat dari model pembelajaran yang digunakan guru dalam proses pembelajaran. Model pembelajaran ExCluSiVE Abdurrahman (2012: 217) menuntut siswa aktif menggali informasi sebanyak-banyaknya pada tahap exploring untuk memahami konsep fisika, kemudian siswa dibimbing guru untuk mengelompokkan informasi yang didapat sesuai dengan ciri dan konsep materi, melakukan simulasi untuk menguatkan pemahaman peserta didik, dan diakhiri dengan mengevaluasi pembelajaran yang dilakukan oleh peserta didik bersama dengan guru. Tahapan pembelajaran tersebut dapat meningkatkan hasil belajar dan kemampuan peserta 
didik untuk berpikir lebih kreatif dalam proses pembelajaran dan sesuai dengan hasil penelitian Khoiri, dkk (2017) berpikir kreatif dapat tercpai pada saat peserta didik melakukan diskusi dan menjelaskan hasil diskusi atau mengemukakan pendapat menggunakan bahasa pilihan mereka.

Pembelajaran dengan menggunakan LKPD berbasis ExCluSiVE telah diuji berdasarkan kemenarikan, kemudahan dan kebermanfaatan diperoleh skor rerata sebesar 3,34 yang berarti produk hasil pengembangan LKPD berbasis ExCluSiVE berada pada kriteria sangat menarik, sangat mudah dan sangat bermanfaat. LKPD berbasis ExCluSiVE ini jika digunakan dalam pembelajaran akan menjadikan peserta didik berfikir lebih aktif, terampil dan kreatif, sesuai dengan peningkatan hasil belajar peserta didik dalam kemapuan berpikir kreatif yang mencapai $34,00 \%$. LKPD tersebut dapat meningkatkan hasil belajar peserta didik, membantu peserta didik dalam menguasai pengetahuan yang dibutuhkan untuk kehidupan sehari-hari, menolong peserta didik untuk dapat mengembangkan disiplin intelektual dan keterampilan berpikir dari rasa keingintahuan peserta didik. Damayanti dkk. (2017) menyatakan bahwa LKPD yang digunakan dalam pembelajaran mampu memicu peningkatan kreativitas pada diri peserta didik, terlebih lagi LKPD yang digunakan merupakan LKPD eksperimen sebagai alat bantu dan pemandu peserta didik saat melaksanakan kegiatan praktikum. Sejalan dengan penelitian yang telah dilakukan oleh Rahayu, dkk. (2011), bahwa penerapan pembelajaran praktikum atau percobaan dengan menggunakan LKPD yang sesuia dapat meningkatkan keterampilan berpikir kreatif siswa.

Pembelajaran dengan menggunakan LKPD berbasis ExCluSiVE berpengaruh cukup tinggi terhadap kemapuan berpikir kreatif peserta didik. Hasil penelitian ini didukung dan mendukung penelitian sebelumnya yang telah dilakukan oleh Mahardika (2013) yang menyatakan bahwa nodel pembelajaran dapat meningkatkan hasil belajar peserta didik, dalam penelitian ini lebih menegaskan hasil belajar dalam berpikir kreatif. Hal ini sesuai dengan data yang telah didapatkan berdasarkan penelitian di kelas eksperimen dan kelas kontrol yaitu rerata $N$ gain kelas eksperimen lebih tinggi dibandingkan dengan kelas kontrol yang menggunakan LKPD konvensional model pembelajaran langsung atau metode ceramah. Skor $N$ gain yang telah didapat ini digunakan untuk mengetahui tingkat pencapain kemampuan berpikir kreatif peserta didik pada ranah kognitif.

Berdasarkan hasil uji Independent Sample T-test perbedaan signifikan pada N-gain antara kelas eksperimen dengan kelas kontrol terlihat pada hasil nilai signifikan sebesar 0,000 pada taraf kepercayaan 95\%. Hal ini dapat disimpulkan bahwa terdapat pengaruh penggunaan LKPD berbasis model pembelajaran ExCluSiVE pada pembelajaran alat alat optik terhadap kemampuan berpikir kreatif peserta didik. Hasil tersebut dengan demikian menyatakan bahwa $\mathrm{H}_{0}$ ditolak dan $\mathrm{H}_{1}$ diterima pada taraf kepercayaan 95\%. Berdasarkan analisis data dan didukung dengan hasil 
penelitian-penelitian sebelumnya, dapat dinyatakan bahwa pembelajaran menggunakan LKPD berbasis ExCluSiVE lebih efektif dibandingkan dengan pembelajaran dengan menggunakan LKPD konvensional model pembelajaran langsung atau metode ceramah.

\section{PENUTUP}

Berdasarkan data hasil penelitian dan pembahasan, dapat disimpulkan bahwa terdapat pengaruh yang signifikan pada pembelajaran alat optik dengan menggunakan LKPD berbasis ExCluSiVE terhadap kemampuan berpikir kreatif yang ditunjukkan berdasarkan perbedaan $N$ gain yang signifikan dengan tingkat signifikansi $<0,05$.

Saran yang diberikan kepada pembaca dan juga peneliti selanjutnya yaitu Hasil kemampuan berpikir kreatif peserta didik yang belum memenuhi KKM karena peserta didik kurang aktif dan kolaboratif dengan temannya, dalam proses pembelajaran. Guru dapat menggunakan media pembelajaran berupa LKPD berbasis ExCluSiVE dengan memberi motivasi yang membangkitkan semangat belajar dan mengajak siswa lebih berperan aktif sebagai alternatif guru-guru di sekolah dan salah satu upaya untuk meningkatkan kemampuan berpikir kreatif peserta didik.Guru dapat memanfaatkan media pembelajaran yang lain berupa simulasi, video pembelajaran, untuk menjelaskan suatu konsep yang tidak dapat dipahami apabila dijelaskkan secara verbal, dengan adanya simulasi ataupun video maka peserta didik dapat memahami konsep secara jelas.

\section{REFERENSI}

Abdurrahman, Wini Tamini, dan Budi Kadaryanto. (2012). Pengembangan Model Pembelajaran Tematik Berorientasi Kemampuan Metakognitif untuk Membentuk Karakter Literate dan Awareness bagi Siswa Sekolah Dasar di Wilayah Rawan Bencana. Prosiding Seminar Nasional Pendidikan Sains. UNS, Solo.

Amer, Ayman. (2005). Analytical Thinking. Mesir: CAPSCU.[online].http://www.pathways.cu.edu.e g.diakses pada tanggal 25 September 2018).

Baer, J. (2014). Creativity and Divergent Thinking: A Task Specific Approach. London: Lawrence Erlbaum Associates Publisher.

Damayanti, A. (2017). Pengembangan Lkpd Berbasis Model Pembelajaran Exclusive Untuk Menumbuhkan Keterampilan Berpikir Kreatif Siswa. Jurnal Pembelajaran Fisika. 5 (4).

Emzir. (2012). Metodologi Penelitian Pendidikan: Kuantitatif dan Kualitatif. Jakarta: Rajawali Pers. 
Sains Siswa Kelas X Sma Negeri 1 Teras Boyolali Tahun Pelajaran 2011/2012. Jurnal Pendidikan Biologi. 4 (2).

Khoiri, N., Slamet Riyadi, Ummi Kaltsum, Nathan Hindarto dan Ani Rusilawati. (2017). Teaching Creative Thinking Skills with Laboratory Work. International Journal of Science and Applied Science: Conference Series. 2 (1).

Mahardika, Mitha P., Abdurrahman dan Feriansyah Sesunan. (2013). Perbandungan Hasil Belajar Model Exclusive dengan Model Direct Instruction. Jurnal Pembelajaran Fisika. 1 (5).

Munandar, U. (2004). Pengembangan Kreativitas Anak Berbakat. Yogyakarta: Rineka Cipta.

Pahini, Nani., Abdurrahman dan Wayan Suana. (2014). Pengaruh Skill Multirepresentasi Siswa Terhadap Hasil Belajar Fisika Pada Model Pembelajaran Exclusive. Jurnal Pembelajaran Fisika. 2 (5).

Pusfarini. (2016). Pengembangan Lembar Kerja Peserta Didik Model Pembelajaran Berbasis Masalah yang Mengamodasi Gender untuk Meningkatkan Keterampilan Berpikir Kreatif Siswa SMP pada Materi Sains. Thesis. Bandarlampung: FKIP Magister Keguruan IPA.

Rahayu, E., Susanto, dan Yulianti, D. (2011). Pembelajaran Sains dengan Pendekatan Keterampilan proses untuk Meningkatkan Hasil Belajar dan Kemampuan Berpikir Kreatif Siswa. Jurnal Pendidikan Fisika Indonesia. 7 (1).

Saefudin, A. (2012). Pengembangan Kemampuan Berpikir Kreatif Siswa Dalam Pembelajaran Matematika Dengan Pendekatan Pendidikan Matematika Realistik Indonesia (PMRI). Jurnal Al Bidayah. 4 (1).

Sagala, Syaiful. (2005). Konsep dan Makna Pembelajaran. Bandung: Alfabeta.

Sujadi, Eko., Meditamar, Muhd. Odha., Ahmad, Bukhari., Rahayu, Anita. (2018). Pengaruh Konsep Diri dan Locus of Control Terhadap Motivasi Berprestasi. Educational Guidance and Counseling Development Jounal, 1 (1): 32-51. dx.doi.org/10.24014/egcdj.v1i1.4808 